\title{
LARGE-EDDY SIMULATION IN LOW WIND CONDITIONS
}

\author{
Domenico Anfossi ${ }^{1}$, Silvana Maldaner ${ }^{2}$, Luca Mortarini ${ }^{1}$, Umberto Rizza $^{3, *}$, Gervásio Annes \\ Degrazia $^{2}$, Marcello Mario Miglietta ${ }^{3}$ \\ ${ }^{1}$ Institute of Atmospheric Sciences and Climate (ISAC) of the Italian National Research Council (CNR), Unit \\ of Turin, Italy \\ ${ }^{2}$ Departamento de Física, Universidade Federal de Santa Maria, RS-Brasil \\ ${ }^{3}$ Institute of Atmospheric Sciences and Climate (ISAC) of the Italian National Research Council (CNR), Unit \\ of Lecce, Italy \\ *u.rizza@isac.cnr.it
}

\section{RESUMO}

Os resultados preliminares de uma simulação dos grandes turbilhões (LES) em uma camada limite convectiva com vento fraco são apresentados. Uma simulação LES foi realizada incluindo, na superfície, a teoria de similaridade de Monin-Obukhov e a teoria de convecção natural. Os resultados foram comparados com radiossondagens e observações superficiais realizadas no CNR (Italian National Research Council) de Torino (em 22 de setembro de 2007), Itália. O modelo LES mostrou-se capaz de descrever uma condição atmosférica de baixa velocidade do vento.

\section{INTRODUCTION}

The knowledge of the Planetary Boundary Layer (PBL) wind calm conditions is of fundamental importance in meteorological and dispersion studies. In particular, the study of pollutants dispersion in low wind speeds (LWS) conditions are generally considered very critical conditions (Anfossi et al., 2005). In LWS the state of the lower PBL is generally not well defined and difficult to predict, thus most dispersion models presents limitations to describe this physical phenomenon (Anfossi et al., 2006; 2010). According to Anfossi et al. (2005) the range of LWS is not outlined but in many applications it is considered less than $1.5 \mathrm{~ms}^{-1}$. To investigate this critical phenomenon we have performed a Large-Eddy Simulation study under realistic conditions (Rizza et al., 2012) in which the setup of the LES has been implemented from soundings and surface measurements conducted at the CNRTurin (Mortarini et al., 2013). 


\section{SIMILARITY THEORY FOR LOW-WIND CONDITIONS}

In this study, LES runs were performed to investigate the atmosphere under lowwind conditions. The theory of Monin-Obukhov similarity theory and free convection were used in the LES model. Thus, surface measurements of sensible and latent heat flux were used to compute the temperature and humidity similarity scales. In highly unstable conditions $(z / L \rightarrow-\infty)$ the friction velocity at surface ceases to be a scaling parameter and is replaced by (Wyngaard et al. 1971):

$$
u_{f}=\left(z\left(z / \theta_{v}\right)\left(\overline{w^{\prime} \theta_{v}}\right)_{0}\right)^{1 / 3}
$$

and the temperature scale is estimated by

$$
\theta_{f}=\left(\left(\overline{w^{\prime} \theta_{v}}\right)_{0} / z\left(g / \theta_{v}\right)\right)^{1 / 3}
$$

\section{LES SETUP}

The LES model is initialized with observational meteorological fields measured in Turin (in northern Italy) at 07 UTC, 22 September, 2007. A $(5,5,2) \mathrm{km}$ box domain with $(128,128,192)$ points in each direction $(x, y, z)$ has been used. The simulations results were compared with atmospheric observations and are shown in Figure 1. This figure exhibits the behaviour of the vertical profile of mean wind and of temperature profile at 10 UTC. The lines with points represent the Turin data and the continuous line is the LES data. The results show a good agreement between the LES results and the observed data, particularly, in the lower PBL.

\section{CONCLUSIONS}

In this preliminary work, we presented a simulation of flow under low wind conditions. The similarity theory coupled with the local free convection theory can be a solution to simulate the flow in atmospheric calm conditions. 


\section{ACKNOWLEDGMENTS}

This work has been supported by Brazilian Research Agencies: CAPES, CNPq and FAPERGS.

\section{REFERENCES}

ANFOSSI, D., OETTl, D., DEGRAZIA, G., GOUlART A. An Analysis of Sonic Anemometer Observations In Low Wind Speed Conditions. Boundary-Layer Meteorology 114, 179-203, 2005.

ANFOSSI D., ALESSANDRINI S., TRINI CASTELli S., FERRERO E., OETTL D., DEGRAZIA G. Tracer dispersion simulation in low wind speed conditions with a new 2-D Langevin equation system. Atmospheric Environment, 40, 7234.7245, 2006.

ANFOSSI D., TINARELli G., TRINI CASTELli S.,FERRERO E., OETTL D., DEGRAZIA G., MORTARINI L. Well mixed condition verification in windy and low wind speed conditions. Int. J. Environment and Pollution, 40, 49-61, 2010.

MORTARINI, L., FERRERO, E., FALABINO, S., TRINI CASTELli, S., RICHIARDONE, R. and ANFOSSI, D. Low-frequencyprocesses and turbulence structure in a perturbed boundary layer. Q.J.R.Meteorol. Soc., 139: 1059-1072. doi: 10.1002/qj.2015, 2013.

RIZZA, U., MiglietTA, M. M., ACEVEDo, O. C., ANABOR, V., DEGRAZIA, G. A., GOULART, A. G. AND ZIMMERMAN, H. R, Large-eddysimulationoftheplanetary boundary layer under baroclinic conditions during Day time and sunset turbulence. Meteorol. Appl. 20: 56-71, doi: 10.1002/met.1284, 2012.

WYNGAARD, J. C., COTÉ,O. R., IZUMI,Y. Local Free Convection, Similarity, and the Budgets of Shear Stress and Heat Flux. Journal of the Atmospheric Sciences 28, 1171$1182,1971$. 
DOI: $10.5902 / 2179460 \mathrm{X} 11698$

Revista do Centro de Ciências Naturais e Exatas - UFSM

Revista Ciência e Natura, Santa Maria

EISSN: 2179-460X, Edição Esp. Dez. 2013, p. 520 - 523 ciênciaenatura



fields at D22: 10 Z



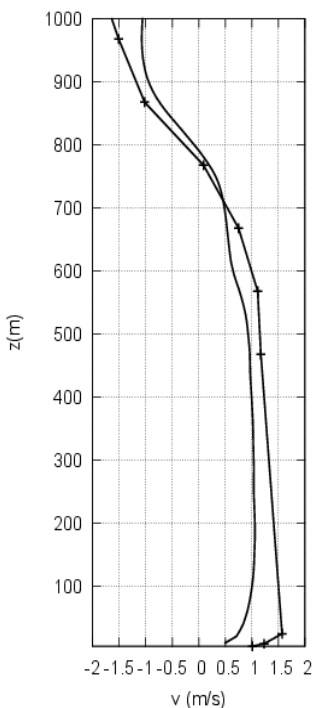

Figure 1. LES simulation and atmospheric soundings. 